\title{
Examining the Viability of Istisna for Project Financing: An Economic Perspective
}

\author{
Muhammad Najihuddin Nasucha, \\ Riazuddin Ahmed, \\ Galad Mohamed Barre
}

\section{International Islamic University Malaysia}

\begin{abstract}
:
The objective of this paper is to examine the viability of Istisna for project financing, with a special focus on its economic aspects and the risks associated with the said contract. This paper also aims to investigate the challenges faced by Islamic banks in adopting Istisna as a mode of project financing. This paper first provides an overview of Shariah-compliant project financing; it then discusses the characteristics of Istisna and barriers to Istisna implementation for construction and infrastructure project development. Economic and general legal considerations are key factors that influence the development of Istisna as project financing. This paper also seeks to explore ways to increase the use of Istisna.
\end{abstract}

Keywords: Istisna; Viability; Risk Management; Project Financing; Constraints; Infrastructure Development; Islamic Project Finance 


\section{Introduction}

Real estate and infrastructure developments are fundamental to national economic growth. Malaysia's openness to trade and investment has positioned it as a competitive and robust Islamic finance marketplace for global investors, including financial institutions and real estate developers. According to the Islamic Financial Services Board (IFSB) (2018) global Islamic banking assets totalled USD 2 trillion at the end of 2017 and Malaysia accounts for nearly 10\% of the total assets. As one of the leading global hubs of Islamic banking and finance, Malaysia has developed a sophisticated Islamic financial system that operates alongside the conventional interest-based financial system.

Istisna (commissioned manufacture) is one of the commonly used modes of financing in infrastructure projects (Chu and Muneeza, 2019; Global Islamic Finance Report, 2016; World Bank, 2017). In Malaysia, Istisna was used a financing facility for the construction of the Kuala Lumpur Light Rail Transit 2 project, one of the successful implementations of Istisna financing projects in the country (Hamwi and Aylward 1999). However, Istisna receives less attention from the Islamic Financial Institutions (IFIs) in Malaysia compared to other modes of financing. Data from the central bank of Malaysia shows that, in 2018, financing from Istisna reached approximately RM2 billion while at the same time financing from Murabahah is valued at RM190 billion and from Bay' Bithaman Ajil is valued at RM 65 billion (Bank Negara Malaysia, 2018).

Given its direct link to physical assets and the real economy, Istisna has the potential to promote economic growth and regional development. By the virtue of Islamic law, the purpose of Istisna is to finance manufactured goods. Experience from Malaysia, however, shows that Istisna financing has contributed only a tiny portion of the total financing offered by IFIs. The under-utilisation of Istisna has raised a question regarding its viability for project financing. Although the literature related to Islamic project financing is growing steadily, discussion on the viability of Istisna as project financing is quite limited. Thus, this paper aims to fill the gap by looking at its economic aspect and potential challenges for financiers and key stakeholders.

\section{An overview of Istisna}

The word Istisna comes from the Arabic word Sina'a, which means to produce a specific commodity (Habib 2018). Bank Negara Malaysia (2015, p. 5) define Istisna as "a contract [by] which a seller sells to a purchaser an asset which is yet to be constructed, built or manufactured according to agreed specifications and [to be] delivered on an agreed specified future date at an agreed pre-determined price". This definition indicates that delivery date and price are pre-determined before the Istisna contract is signed between the seller and purchaser. As a general rule, it is not permitted to sell a commodity or asset which is not in the possession of the seller at the time of sale. Istisna is one of the exceptions to this general rule since it helps to meet the financial need of sellers and basic needs (shelter and clothing) of buyers.

International Journal of Management and Applied Research, 2019, Vol. 6, No. 4 
Hadith says: "Do not sell what is not with you" (Narrated by Hakim bin Hizam, 2187; Amr bin Shuaib, 2188; Abu Dawfid, 2187). According to Kamali (1996), there are different interpretations regarding the Hadith proof-text "Do not sell what is not with you". First, it could mean something you do not own, this interpretation is widely shared among the majority of Muslims jurists. A second position is that, selling "what is not with you" means selling something that cannot be delivered at the time of purchase. This view puts the emphasis on the inability of the seller to deliver, which entails risk and uncertainty (Gharar). In other words, ownership or possession is less important than the ability to deliver goods and fulfil contractual obligation. A third position is that the prohibition on selling "what is not with you" does not apply to fungible goods that can be easily substituted. Using examples such as runaway camels and uncertainty over delivery, Kamali (1996) suggested that this hadith prohibits specified objects, rather than goods that are not owned or present at the time of purchase. To summarise, the prohibition of selling "what is not with you" is open to different interpretations and it could refer to 1) a total ban on sale of something not in ones possession; 2) a ban on selling something that cannot be delivered at the time of sale; 3) a ban on specified objects.

Muslim jurists established the legality of Istisna contract from different legal sources: the Sunnah, Ijma, Qiyas, Istihsan, and Maslahah. According to Bank Negara Malaysia (2015, p. 5): "The legitimacy of the Istisna contract is founded on the basis of the Sunnah of the Prophet Muhammad Peace Be Upon Him (PBUH) and the consensus of the Muslim Jurists (Ijma)". The Prophet (PBUH) had requested the manufacture of a golden ring (Sahih al-Bukhdri, 965); this Hadith provides a legal basis for the permissibility of Istisna even though there is no evidence to suggest that the ring was made under an Istisna contract. Muslim jurists argue that the terms and conditions are specified in the Istisna contract and thus there is no uncertainty (Gharar) and for that reason, Istisna is a contract in accordance with Qiyas and Ijma (Al-Amine, 2001). Additionally, Hanafis maintain that Istisna is permissible on the basis of Istihsan (juristic discretion or preference). Regarding the legal basis of Istisna for the public interest (Maslahah), manufacturing everyday items like shoes and furniture is a illustration of general need and thus Istisna should be permitted on the basis of public interest (Al-Amine, 2001).

To sum up, Islamic law prohibits uncertain sales and to avoid uncertainty financial contracts such as Istisna need to be as detailed as possible. Contacting parties must set and agree on performance standards to be met, completion time, appropriate costing, as well as payment options.

\subsection{Istisna and Parallel Istisna}

In a typical Istisna contract a buyer pays the seller (or builder) and the seller in turn delivers the specified goods at agreed time. Figure 1 illustrates the transactional relationship between the two in a 'simple Istisna'.

International Journal of Management and Applied Research, 2019, Vol. 6, No. 4 
Figure 1: Simple Istisna

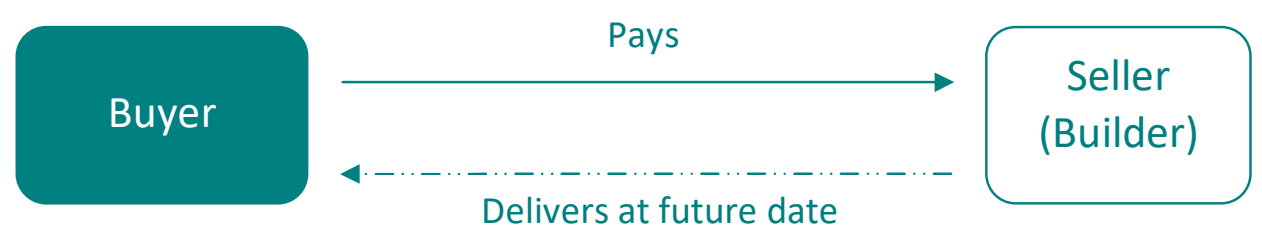

In modern Islamic banking, however, banks are not in the business of buying and selling goods; rather, they are in the business of financing companies manufacturing goods or providing services (Habib, 2018). The contracting parties of an Istisna contract may enter into parallel Istisna, another Istisna contract with specifications identical or similar to those of the first Istisna contract. Parallel Istisna consists of two mutually independent Istisna contracts, which exists on both sides; between the consumer and bank, and between the bank and builder. Islamic financiers act as an intermediary in the financing of construction projects by entering into an Istisna contract with the buyer and, at the same time, entering into a second Istisna contract with the builder. Figure 2 illustrates the contractual relationships between the contracting parties.

Figure 2: Parallel Istisna

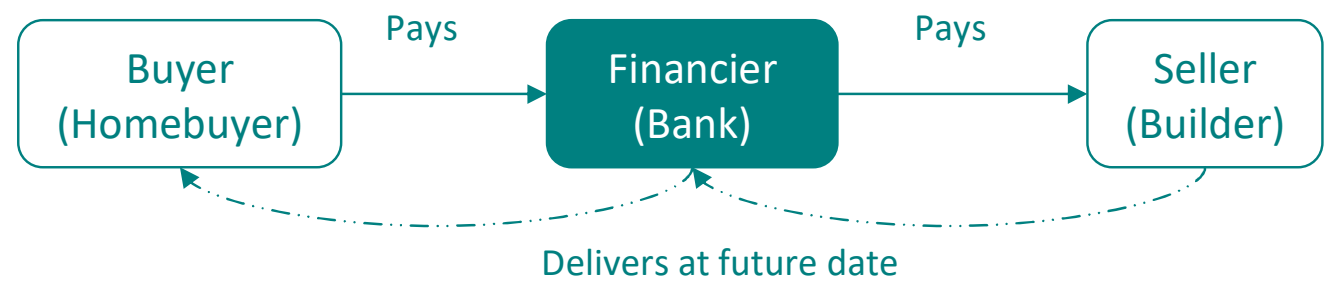

The bank pays the builder while the consumer (or homebuyer) pays the bank according to the agreed terms and conditions. The builder then delivers the end product to the bank according to repayment schedule. The repayment period for the contract varies according to the agreement between the contracting parties; the payment can be made in advance, by instalments during the construction, at or after completion (Hasmawati and Mohamad, 2019). Although full specifications of the end product are identical in both contracts, the price and payment options would be different because the price difference is the profit made by the bank for financing the construction project (Habib, 2018).

It is important to highlight that these two contracts are completely independent of each other and the bank cannot pass on the loss of one contract to another. Given the structure of the Istisna contract, the bank may face financial losses if the builder is unable to deliver the asset on time (Akkizidis and Khandelwal, 2008). The bank is also exposed to a high risk of default from both homebuyer and builder (Habib, 2018), especially in the absence of collateral from the buyer and warranty from the builder.

International Journal of Management and Applied Research, 2019, Vol. 6, No. 4 
The liability exposures of the bank in this regard "has been an impediment to widespread acceptance of the structure by many banks and financial institutions" (McMillen, 2007, p. 220). For that reason, great care must be taken in order to prevent default risk and damage liability.

\subsection{Risk Management in Islamic Project Financing}

Construction projects and infrastructure development are capital intensive. The capital requirement often exceeds the capacity of a single company and thus there is a need for project financing. Istisna is suitable for real estate and infrastructure developments because it is a flexible Islamic manufacturing contract which can accommodate the involvement of other parties (Lahsasna et al., 2018). In a study of 18 Islamic bankers regarding their perception of the risks inherent in various Islamic modes of financing, Istisna was perceived as risky due to the high possibility of production failure (Ahmed and Khan, 2007) and constant exposure to operational risk during the construction period (Akkizidis and Khandelwal, 2008).

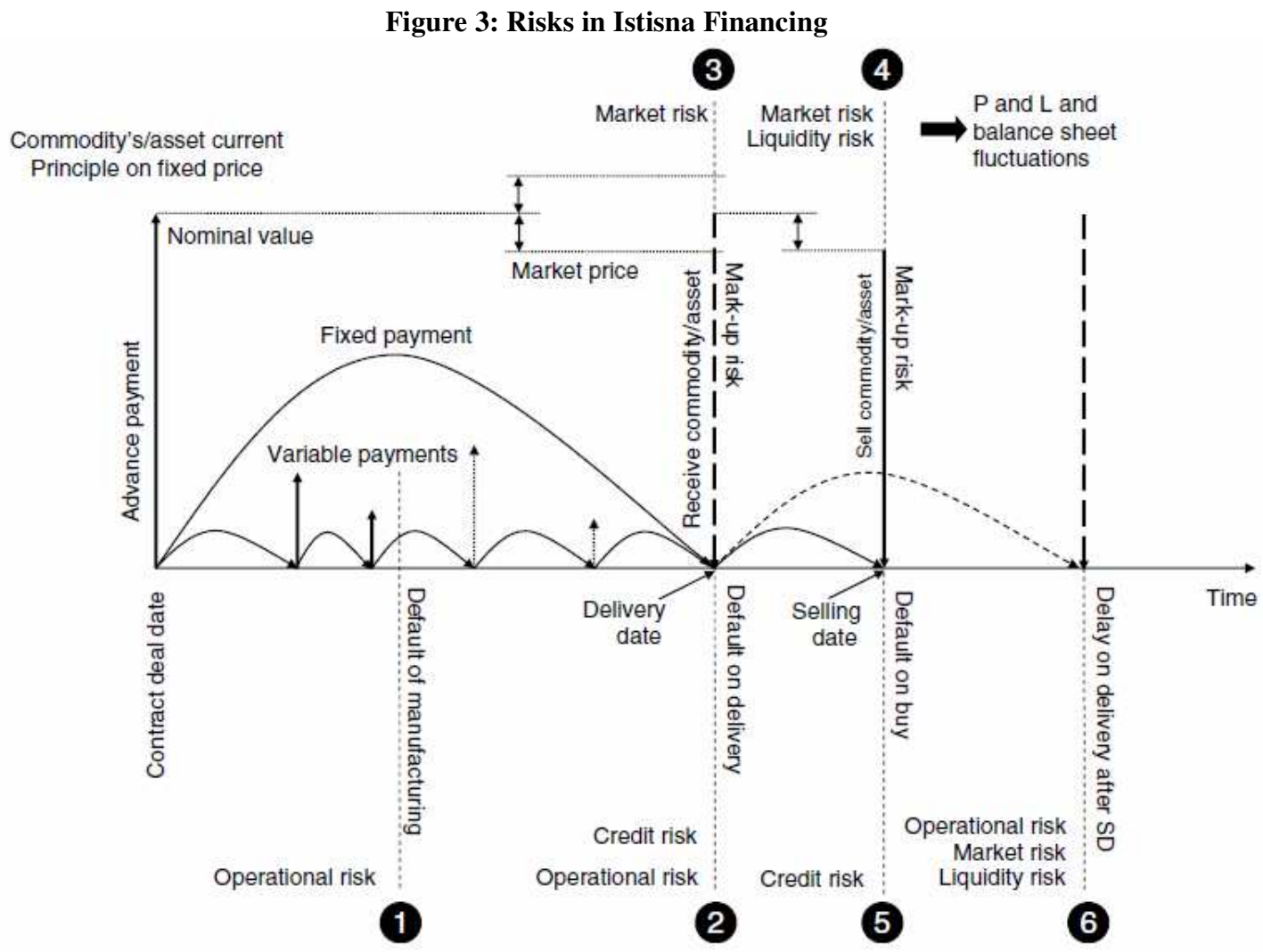

Source: Akkizidis and Khandelwal (2008, p. 66)

The inability of the builder to deliver the asset on time may cause further delays or even termination of the contract, which could result in financial losses due to additional expenditures and loss of opportunity cost. The Islamic financier also faces

International Journal of Management and Applied Research, 2019, Vol. 6, No. 4 
market risk, where price differentiation between the actual market price and the estimate occurs due to market fluctuation (Akkizidis and Khandelwal, 2008). Additionally, bankers also perceive that Istisna has a high liquidity risk due to its product-deferred instrument. In the Istisna contract, the Islamic financier is exposed to liquidity risk (see Figure 3, at points 4 and 6) in the event of default (Akkizidis and Khandelwal, 2008).

Common approaches to mitigation of the aforementioned risks include; reservation of adequate capital to cover financial losses (Akkizidis and Khandelwal, 2008), insuring the property. The seller in Istisna is responsible for insuring the asset (Habib, 2018). In instances where insurance is insufficient to mitigate risks, the Islamic financier acts through a special purpose vehicle (SPV) to ring-fence their financial liabilities (World Bank, 2017). The use of SPV to act on behalf of the Islamic financier as the buyer under an Istisna agreement protects the financier from potential liabilities (e.g. property damage, non-completion, environmental liability). If a cost overrun occurs in a project under Istisna contract, the Islamic financier has no obligation to pay the excess (World Bank, 2017).

Another common banking practice is to break the contract into smaller contracts with phased payments (Habib, 2018). To reduce risk of delayed delivery, the bank pays the builder or contractor conditional on completion of the previous phase (Akkizidis and Khandelwal, 2008), the milestone completion certificate with various deliverables is similar to a conventional loan disbursement request (McMillen, 2007); Furthermore, the drafting of the Istisna contract should also incorporate damage limitation provisions, inspection rights and appropriate waivers of liability to address the liability exposure of the bank (McMillen, 2007).

The table below summarises the typical risks in an Istisna contract and common approaches adopted by Islamic financiers to reduce those risks.

Table 1: Risk mitigation strategies

\begin{tabular}{ll}
\hline Area of risk & Risk mitigation technique \\
\hline $\begin{array}{l}\text { Liquidity risk: failure to generate enough } \\
\text { cash flow in financing }\end{array}$ & Financier can arrange phased payments \\
$\begin{array}{l}\text { Delivery risk: unable to deliver the property } \\
\text { on time }\end{array}$ & $\begin{array}{l}\text { Financier can avoid paying cost-overruns } \\
\text { by initiating a SPV in the case of delay }\end{array}$ \\
$\begin{array}{l}\text { Default risk: failure to repay } \\
\text { Financier can obtain collateral from the } \\
\text { buyer and warranty from the builder }\end{array}$ \\
$\begin{array}{l}\text { Market risk: price differentiation between } \\
\text { actual market price and estimate due to } \\
\text { market fluctuation }\end{array}$ & $\begin{array}{l}\text { Financier can make arrangement with } \\
\text { Insurance agency }\end{array}$ \\
$\begin{array}{l}\text { Operational risk: malfunctioning } \\
\text { machinery, injury, weather, human errors, } \\
\text { etc. }\end{array}$ & $\begin{array}{l}\text { Financier can transfer operational risk to a } \\
\text { SPV }\end{array}$ \\
\hline
\end{tabular}

Adapted from: Lahsasna et al. (2018, p. 133)

International Journal of Management and Applied Research, 2019, Vol. 6, No. 4 


\section{The Economic Viability of Istisna Financing}

Theoretically, Istisna is a promising mode of financing for economic growth and regional development; however, in practice Islamic financiers are exposed to greater risks than conventional financial institutions which offer interest-based loan to fund similar projects. Like conventional banks, it is imperative for Islamic financial institutions to estimate the probability of default and reserve sufficient capital to cover financial losses (Akkizidis and Khandelwal, 2008). Nonetheless, Islamic financiers are liable for losses for which conventional banks had not assumed responsibility, such as property damage and non-completion (Hasmawati and Mohamad, 2019). Instead of a lender-borrower relationship, the buyer-seller relationship in the Istisna contract indicates the contractual obligation of the financier towards the end-buyer, which adds an additional legal burden on the financier.

It is therefore important for financiers to consider the viability and incentive compatibility of Islamic modes of financing in leveraging their resources, with an emphasis on achieving high fund mobilisation ratios (Hamwi and Aylward, 1999).

As Dar (2007, p. 86) pointed out: "For a financial structure to work on its own, the transacting parties involved should have sufficient incentives to stick with the contract otherwise the structure will make little sense".

The arguments for Istisna are mostly ideological. Researchers like Hasmawati and Mohamad (2019) is not reflected in practice because Istisna is one of the least utilised Islamic financial instruments (Alzoubi, 2017; Bank Negara Malaysia, 2018; World Bank, 2017). According to Alzoubi (2017), the under-utilisation of Istisna is because it requires more effort than other Islamic financial instruments. Similarly, Hasmawati and Mohamad (2019) found that bankers generally perceive Istisna as a risky mode of financing because of concerns about not meeting product specifications and parameters set by local authority bodies. Looking at 17 participants from 13 banks in Malaysia, Hasmawati and Mohamad (2019) reported that Istisna contracts were withdrawn from the market due to the high benchmark set by the central bank of Malaysia. In other words, some Islamic banks withdrew Istisna from the market not just because of economic considerations but due to legal constraints.

An Islamic financial institution is not obliged to offer a financial product simply because the product is Shariah-compliant. The decision to offer a financial product or service is based on a careful analysis of risk, cost, benefit and profitability. Other Shariah-compliant financing which is suitable for project finance such as Ijarah (lease) is less risky and requires less effort when compared to Istisna (Alzoubi, 2017; Hasmawati and Mohamad, 2019; World Bank, 2017).

Alzoubi (2017) provided a financial argument for Istisna. According to Alzoubi (2017, p. 79), "the profit margin of Istisna financing is be more flexible than the Murabaha rate, which is usually controlled by the central bank. Consequently, Istisna financing is expected to make a greater contribution to overall profit". This argument for Istisna could be convincing for Islamic financiers operating in MENA countries where the Murabaha rate is controlled by the central bank. In other Muslim-majority countries, however, Islamic financial institutions have the option of setting profit margins and

International Journal of Management and Applied Research, 2019, Vol. 6, No. 4 
mark-up rates freely. In Malaysia, for example, the mark-up for Murabaha "may be determined either in the form of an absolute amount or a certain percentage of the acquisition cost or a reference rate such as the Base Lending Rate (BLR), the Base Financing Rate (BFR), Kuala Lumpur Interbank Offered Rate (KLIBOR) or Cost of Funds (COF)" (Bank Negara Malaysia, 2013, p. 13). In short, the financial argument for Istisna as given by Alzoubi (2017) does not apply in all countries.

Among the strongest arguments for Istisna is that Islamic financial institutions can diversify their investment portfolio with the use of Istisna (Al-Amine, 2001). It is not feasible for Islamic banks to expand their businesses solely based on interest-free loans and bridge financing. While Islamic financiers could invest in construction projects through leasing (Ijarah) and sale (Murabaha), Istisna offers greater flexibility in terms of payment options and profit margins. Moreover, homebuyers and financiers often raise concerns over the tax implications of Islamic financial instruments; for example, the use of Ijarah entails a higher tax burden for the Islamic financier than a conventional interest-based loan (Ariff and Rosly, 2011). However, an Islamic financier who uses Istisna can claim a tax deduction in some countries. For example, the Tax Matters Agreement under an Istisna contract is structured in a way that it allows the Islamic financier to claim a tax benefit in the United States (McMillen, 2000). However, such tax relief is not available in all countries.

At a regional level, the use of Istisna could promote economic growth and new job creation (Al-Amine, 2001). As part of quality control, it is necessary for Islamic financiers to inspect and monitor the construction process (McMillen, 2007). This additional layer of contractual obligation creates a need to hire manpower or to create a special unit to oversee the entire project. There is also a need to invest heavily in human resources and reorganisation. On top of that, economic growth and regional development depend on infrastructure; namely reliable access to fresh water, efficient telecommunications, availability of public transportation and power supplies (Hamwi and Aylward, 1999).

Infrastructure development has a long-term impact on economic development because it not only improves the provision of basic infrastructure services and living standards but also creates job opportunities. Investing in infrastructure projects also accords with the Shariah principle of participating in the real economy in a socially responsible manner (Hamwi and Aylward, 1999). With an emphasis on investment in the real economy, Shariah principles ensure that capital does not lead to inflation or artificially bloated property prices. The project financing structure is a form of asset-based financing that is consistent with Shariah principles. An increased use of Istisna could lead to a further development of the Islamic finance industry in which Islamic financial institutions play a more active role as project owner to mobilise large funds.

Table 2 summarises the arguments for and against the use of Istisna as project financing.

International Journal of Management and Applied Research, 2019, Vol. 6, No. 4 
Table 2: Argument for and against Istisna

\begin{tabular}{lll}
\hline & Argument for & Argument against \\
\hline Economic & $\begin{array}{l}\text { Financier can diversify further their } \\
\text { portfolio using Istisna }\end{array}$ & $\begin{array}{l}\text { It requires intensive capital and } \\
\text { affects cash flow in the event of } \\
\text { default. }\end{array}$ \\
Legal & $\begin{array}{l}\text { It is a Shariah-compliant financial } \\
\text { product. }\end{array}$ & $\begin{array}{l}\text { 1) Financier has contractual } \\
\text { obligation towards end-buyer, a risk } \\
\text { the financier is reluctant to take. } \\
\text { 2) Authorities set high benchmark } \\
\text { that financiers find it hard to comply } \\
\text { with. }\end{array}$ \\
Social & $\begin{array}{l}\text { It is a socially-responsible mode of } \\
\text { asset-based financing. }\end{array}$ & $\begin{array}{l}\text { Other Islamic financial products are } \\
\text { equally socially-responsible. }\end{array}$ \\
\hline
\end{tabular}

\section{Recommendations and Conclusion}

Istisna is a type of asset-backed financing which fits well with the mission of Islamic finance, i.e. investing in the real economy in a socially responsible manner. The nature of this contract can accommodate the financial needs of construction companies and housing need. Shariah principles provide a set of guidelines to structure lawful (Halal) finance deals, including funding tailored for small or large projects. However, Istisna is under-utilised by financial institutions (Hasmawati and Mohamad (2019) due to legal constraints and economic considerations. To overcome these challenges, Islamic financiers need to develop a more robust risk management protocols than they currently adopt.

As in any investment, the impediments must be addressed with care and innovation. A common feature of Islamic project finance in the contemporary setting is the seamless coexistence of multiple Islamic financial instruments. A variety of infrastructure projects combining different Islamic finance structures have proven to be successful in terms of on-time delivery without serious cost-overruns. Take Kuala Lumpur Light Rail Transit 2 project (PUTRA) as an example; two Islamic finance modes were used to finance the project. The Islamic financier used Istisna during the construction phase, when construction was completed the equipment was leased back to the railway operator, PUTRA, through an Ijarah (lease) contract (Hamwi and Aylward, 1999). The combination of Istisna-Ijarah is increasingly common in infrastructure development, as shown in the case studies of World Bank (2017).

Another common banking practice adopted by Islamic financier is to structure Sukuk (Islamic bond) using an Istisna contract (Badri and Mikail, 2014). The issuer of Sukuk Istisna is the builder and interested investors would be the subscriber or holder of Sukuk Istisna. The issuance of Sukuk Istisna plays an important role in raising funds from bond holders, who are entitled to the sale price of the project (Lahsasna et al., 2018). Depending on the structure of Istisna Sukuk, Sukuk holders may receive a lump sum payment or phased payment. Once the project is completed and the asset is sold to

International Journal of Management and Applied Research, 2019, Vol. 6, No. 4 
a third party, the investors will receive a payment (principal plus profit). Alternatively, the holders may receive a staged payment according to the stages of completion of the asset (Badri and Mikail, 2014).

Local government plays an important role in fostering Islamic project finance because some of the challenges faced by Islamic financers could be overcame by government supports. In the case of Madinah Airport, for example, the government will pay the financiers if the project is terminated due to an inability of SPV to complete the project on time and of agreed quality (World Bank, 2017). Tax relief or waivers is another form of government support to encourage Islamic financiers participating in capital intensive infrastructure project. In Malaysia, for example, tax deductions are given for the issuance of Sukuk Istisna (Bank Negara Malaysia, 2007).

To conclude, Islamic financial instruments can be mobilised to realise public interest projects. Debates about the efficiency and effectiveness of each Islamic financial instrument - including Istisna - are inevitable. Depending on the national context and infrastructure need, Istisna would be suited to fund project finance and it may be worthwhile for Islamic financial institutions to invest in the construction industry using Istisna in a more prudent manner.

\section{References}

1. Ahmed, H. and Khan, T. (2007), "Risk management in Islamic banking", in: Hassan, M. K. and Lewis, M. K. (Ed.), Handbook of Islamic Banking, Cheltenham: Edward Elgar Publishing Limited, pp. 144-160. https://doi.org/10.4337/9781847205414.00019

2. Akkizidis, I. and Khandelwal, S. K. (2008), Financial Risk Management for Islamic Banking and Finance, UK: Palgrave Macmillan. https://doi.org/10.1057/9780230598751

3. Al-Amine, M. A. B. (2001), "Istisna and Its Application in Islamic Banking", Arab Law Quarterly, Vol. 16, No. 1, pp. 22-48

4. Alzoubi, T. (2017), "Profitability of Islamic financing tools", Banking and Finance Review, Vol. 9No. 1, pp. 75-83.

5. Ariff, M. and Rosly, S.A. (2011), "Islamic banking in Malaysia: Unchartered waters", Asian Economic Policy Review, Vol. 6, No. 2, pp. 301-319. https://doi.org/10.1111/j.1748-3131.2011.01208.x

6. Badri, M. B. and Mikail, S. A. (2014), Istisna' Sukuk - A Preliminary Glimpse, ISRA [Online] available from: http://www.mifc.com/index.php?ch=48\&pg=203\&ac=93\&bb=uploadpdf [Accessed on 12 June 2019].

7. Bank Negara Malaysia (2007), Sukuk: Efficient Diversification Mechanism and New Asset Class, [Online] available from:

International Journal of Management and Applied Research, 2019, Vol. 6, No. 4 
http://www.bnm.gov.my/files/publication/fsps/en/2007/cp02 001 whitebox.pdf

[Accessed on 12 June 2019].

8. Bank Negara Malaysia (2013), Murabahah, [Online] available from: http://www.bnm.gov.my/guidelines/05 shariah/CP Murabahah 122013.pdf [Accessed on 12 June 2019].

9. Bank Negara Malaysia (2015), Draft Shariah Parameter Reference 5: Istisna Contract RAFT (SPR5) [Online] available from:

http://www.bnm.gov.my/guidelines/05_shariah/06_concept_paper_shariah_para_re f 5_draft.pdf [Accessed on 12 June 2019].

10. Bank Negara Malaysia (2018), 1.18.2 Islamic Banking System: Financing by Concept, [Online] available from: http://www.bnm.gov.my/index.php?ch=en_publication\&pg=en_msb\&lang=en\&m $\underline{\text { nth}}=6 \& y r=2018$ [Accessed on 12 June 2019].

11. Chu, J. and Muneeza, A. (2019), "Belt and Road Initiative and Islamic Financing: The Case in Public Private Partnership Infrastructure Financing", International Journal of Management and Applied Research, Vol. 6, No. 1, pp. 24-40. https://doi.org/10.18646/2056.61.19-002

12. Dar, H. (2007), "Incentive Compatibility of Islamic Financing", in: Hassan, M. K. and Lewis, M. K. (Ed.), Handbook of Islamic Banking, Cheltenham: Edward Elgar Publishing Limited, pp. 85-95. https://doi.org/10.4337/9781847205414.00015

13. Global Islamic Finance Report (2016), Islamic Project Finance: A Growing Trend, [Online] Available from:http://www.gifr.net/gifr2016/ch_08.pdf [Accessed on 12 May 2019].

14. Habib, S. F. (2018), “Chapter 9: Istisna”, in: Habib, S. F. (Ed.), Fundamentals of Islamic Finance and Banking, 155-168. https://doi.org/10.1002/9781119371076.ch9

15. Hamwi, B. and Aylward, A. (1999), "Islamic finance: A growing international market", Thunderbird International Business Review, Vol. 41, No. 4-5, pp. 407420. https://doi.org/10.1002/tie.4270410407

16. Hasmawati, A. and Mohamad, A. (2019), "Potential application of Istisna' financing in Malaysia", Qualitative Research in Financial Markets, Vol. 11, No. 2, pp.211-226. https://doi.org/10.1108/QRFM-07-2018-0083

17. Islamic Financial Services Board (IFSB) (2018), Islamic Financial Services Industry Stability Report 2018, Kuala Lumpur: IFSB.

18. Kamali, M. H. (1996), "Islamic Commercial Law: An Analysis of Futures", The American Journal of Islamic Social Sciences, Vol. 13, No. 2, pp. 197- 224.

International Journal of Management and Applied Research, 2019, Vol. 6, No. 4 
19. Lahsasna, A. and Hassan, K. M. and Ahmad, R. (2018), Forward Lease Sukuk in Islamic Capital Markets, Switzerland: Palgrave Macmillan. https://doi.org/10.1007/978-3-319-94262-9

20. McMillen, M. J. T. (2000), "Islamic Shariah-Compliant Project Finance: Collateral Security and Financing Structure Case Studies", Fordham International Law Journal, Vol. 24, No. 4, pp. 1184-1232

21. McMillen, M. J.T, (2007), "Islamic Project Finance", i", in: Hassan, M. K. and Lewis, M. K. (Ed.), Handbook of Islamic Banking, Cheltenham: Edward Elgar Publishing Limited, pp. 200-240. https://doi.org/10.4337/9781847205414.00024

22. World Bank Group (2017), Mobilizing Islamic Finance for Infrastructure PublicPrivate Partnerships [Online] Available from: https://ppiaf.org/documents/5369/download [Accessed on 12 May 2019].

International Journal of Management and Applied Research, 2019, Vol. 6, No. 4 